DOI: $10.15193 /$ zntj/2017/112/202

\author{
AGATA ZNAMIROWSKA, PRZEMYSŁAW ROŻEK, \\ MAGDALENA BUNIOWSKA, DOROTA KALICKA
}

\title{
DYNAMIKA FERMENTACJI SERWATKI NISKOLAKTOZOWEJ PRZEZ SACCHAROMYCES BAYANUS (BAYANUS G995) ORAZ JAKOŚĆ NAPOJÓW SERWATKOWYCH
}

\author{
Streszczenie
}

Enzymatyczny rozkład laktozy w serwatce przy udziale $\beta$-galaktozydazy pozwala na intensyfikację fermentacji alkoholowej poprzez zwiększenie dostępności cukrów i możliwość zastosowania szczepów mikroorganizmów niefermentujących laktozy, a używanych tradycyjnie w produkcji napojów alkoholowych.

Celem pracy była ocena możliwości zastosowania drożdży BAYANUS G995 (Spirit Ferm, Szwecja) oraz określenie dynamiki fermentacji serwatki z naturalną zawartością laktozy i niskolaktozowej. W pracy przedstawiono wyniki oceny jakości napojów serwatkowych nasyconych $\mathrm{CO}_{2}$.

Fermentację alkoholową prowadzono w temp. $23^{\circ} \mathrm{C}$ przez 28 dni. Co 7 dni nastawy dosładzano sacharozą oraz kontrolowano raz w tygodniu zawartość sacharydów, białka, $\mathrm{pH}$, kwasowość całkowitą oraz po zakończeniu fermentacji - zawartość alkoholu. Po 28 dniach serwatki zlano, wzbogacono o dodatki smakowe i dosłodzono sacharozą. Przeprowadzano refermentację w temp. $25^{\circ} \mathrm{C}$ przez 4 dni w celu nasycenia $\mathrm{CO}_{2}$. Następnie napoje schłodzono do temp. $5^{\circ} \mathrm{C}$ i poddano ocenie sensorycznej i fizykochemicznej. Saccharomyces bayanus G995 mogą być wykorzystywane do produkcji napojów nasyconych $\mathrm{CO}_{2} \mathrm{z}$ serwatki z naturalną zawartością laktozy i niskolaktozowej. Po 28 dniach fermentacji w napojach niskolaktozowych stwierdzono o $1 \%$ większą zawartość alkoholu niż w napojach z naturalną zawartością laktozy, odpowiednio: 9,50 i 8,50\%. Podczas 28 dni fermentacji w nastawach serwatki z laktozą wartość pH obniżyła się o 0,5 jednostki (z 4,56 do 4,06), a w napojach niskolaktozowych - o 0,45 jednostki (z 4,50 do $4,05)$. W czasie fermentacji odnotowano także systematyczny wzrost kwasowości całkowitej nastawów z naturalną zawartością laktozy (z $0,36 \mathrm{~g} / 1 \mathrm{w} 0$. dniu do $0,67 \mathrm{~g} / 1 \mathrm{w} 28$. dniu) i niskolaktozowych (z 0,46 g/l w 0 . dniu do $0,69 \mathrm{~g} / 1 \mathrm{w} 28$. dniu). Napoje otrzymane z serwatki niskolaktozowej charakteryzowały się większą klarownością, lepszą barwą oraz intensywniejszym słodszym smakiem w porównaniu z napojami wyprodukowanymi z serwatki o tradycyjnej zawartości laktozy.

Słowa kluczowe: serwatka, Saccharomyces bayanus, napoje niskolaktozowe, fermentacja

Dr hab. inż. A. Znamirowska, prof. nadzw., mgr inż. P. Rożek, dr inż. M. Buniowska, dr inż. D. Kalicka, Zakład Technologii Mleczarstwa, Wydz. Biologiczno-Rolniczy, Uniwersytet Rzeszowski w Rzeszowie, ul. Ćwiklińskiej 2D, 35-601 Rzeszów. Kontakt:aznam@univ.rzeszow.pl 


\section{Wprowadzenie}

Konkurencja na rynku mlecznych napojów fermentowanych i zwiększający się popyt na żywność funkcjonalną sprzyjają rozwojowi nowego kierunku przetwórstwa serwatki $[26,30]$. Serwatka jest korzystnym środowiskiem dla wzrostu oraz rozwoju wielu mikroorganizmów i może być dobrym surowcem do produkcji napojów. Zawiera białka, które są wartościowe pod względem odżywczym [7, 17]. Dla współczesnego odbiorcy ważne są nie tylko: tekstura, aromat i smak, ale też obniżona kaloryczność. Produkty na bazie serwatki mogą spełnić te wymagania [9]. Opracowano wiele receptur produktów serwatkowych, jednak charakterystyczny, niepożądany aromat i smak serwatki utrudniają prace projektowe [29]. Ponadto jednym ze składników serwatki jest laktoza, która jest eliminowana z diety przez osoby z nietolerancją laktozy, wynikającą z niedoboru lub wręcz braku laktazy w organizmie [1]. Laktaza jest szeroko stosowana w farmakologii i produkcji żywności. Wykorzystuje się ją m.in. do częściowej hydrolizy laktozy podczas wytwarzania mleka zagęszczonego w celu uniknięcia krystalizacji tego cukru w produkcie gotowym. Stosuje się ją również do produkcji napojów z mleka i serwatki, lodów, produktów kandyzowanych [29]. Enzymatyczny rozkład laktozy w serwatce czy też w permeacie przy udziale $\beta$-galaktozydazy umożliwia intensyfikację fermentacji alkoholowej poprzez zwiększenie dostępności cukrów i możliwość zastosowania szczepów mikroorganizmów niefermentujących laktozy, a używanych tradycyjnie w produkcji napojów alkoholowych $[18,28]$. Aktywatorami procesu fermentacji alkoholowej prowadzonej przez drożdże są głównie witaminy, enzymy i niektóre związki mineralne. Do prawidłowego wzrostu i rozmnażania drożdży niezbędne są witaminy $\mathrm{z}$ grupy $\mathrm{B}$, m.in. tiamina, biotyna i kwas pantotenowy. Z substancji mineralnych największe znaczenie mają: magnez, potas, wapń i sód [11]. W serwatce makro- i mikroelementy występują w wystarczającej ilości, także ryboflawina, biotyna, pirydoksyna i witamina $B_{12}$ [29]. Napoje bezalkoholowe ze zhydrolizowaną laktozą są łatwe w produkcji i charakteryzują się niską wartością energetyczną ok. $110 \mathrm{kcal} / 100 \mathrm{ml}$, dzięki czemu są chętnie spożywane przez szeroką grupę konsumentów. Napoje niskolaktozowe są jednak nietrwałe i do ich produkcji stosuje się substancje konserwujące. Konieczne jest więc opracowanie receptur napojów bez użycia konserwantów [17, 18, 28].

Celem pracy była ocena możliwości zastosowania drożdży BAYANUS G995 oraz określenie dynamiki fermentacji serwatki niskolaktozowej i z laktozą. W pracy przedstawiono wyniki oceny jakości napojów serwatkowych nasyconych $\mathrm{CO}_{2}$.

\section{Material i metody badań}

Napoje produkowano z pasteryzowanej serwatki podpuszczkowej pochodzącej z produkcji sera salami, o składzie chemicznym: białko $-0,60 \%$, laktoza $-4,73 \%$, 
thuszcz $-0,35 \%$. Serwatkę dzielono na 2 części, do pierwszej dodawano laktazy i przechowywano ją przez $12 \mathrm{~h}$ (temp. $8-10^{\circ} \mathrm{C}$ ), a drugą przechowywano bez dodatku enzymu (temp. $8-10^{\circ} \mathrm{C}$ ). Stosowano laktazę Lacta-Free (Biochem s.r.l., Włochy) w ilości 2 g/l serwatki, co zgodnie z deklaracją producenta powodowało hydrolizę laktozy na poziomie $99 \%$.

Następnie w obu serwatkach prowadzono fermentację mlekową (18 h, temp. 22 $25^{\circ} \mathrm{C}$ ) z udziałem szczepionki CHN19 (Chr. Hansen, Dania) o składzie: Lactococcus lactis subsp. lactis, Lactococcus lactis subsp. cremoris, Leuconostoc mesenteroides subsp. cremoris, Lactococcus lactis subsp. lactis var. diacetylactis. W serwatce z naturalną zawartością laktozy (tradycyjnej) i niskolaktozowej oznaczano kwasowość całkowitą i pH oraz zawartość: tłuszczu, białka, węglowodanów. Obie serwatki pasteryzowano (temp. $95^{\circ} \mathrm{C}, 30 \mathrm{~min}$ ) i po schłodzeniu do temp. $30{ }^{\circ} \mathrm{C}$ filtrowano. Serwatki dosładzano sacharozą (40 g/l serwatki) i dodawano drożdże Saccharomyces bayanus Bayanus G995 (Spirit Ferm, Szwecja). Optymalna temperatura fermentacji Bayanus G995 to $20-25{ }^{\circ} \mathrm{C}$. Stosowane są do produkcji win, wznawiania fermentacji, refermentacji i produkcji napojów musujących. Główną zaletą tych drożdży jest zdolność do pracy w trudnych warunkach (niskie: temperatura i pH, małe stężenie składników odżywczych) i zdolność fermentacji alkoholu do 16,5 - 17 \% [19]. Fermentację prowadzono w temp. $23{ }^{\circ} \mathrm{C}$ przez 28 dni. Nastaw dosładzano co 7 dni sacharozą ( $40 \mathrm{~g} / 1 \mathrm{ser}-$ watki) oraz kontrolowano raz w tygodniu zawartość sacharydów, białka, pH i kwasowość całkowitą. Po 28 dniach serwatki zlewano, dosładzano sacharozą (40 g/l) oraz dodawano esencji „Mango - marakuja” (Biowin, Polska) w ilości $10 \mathrm{ml} / 1$ serwatki. Napoje rozlewano do butelek o pojemności 1 litra i zakręcano zakrętkami. Przeprowadzano refermentację w temp. $25^{\circ} \mathrm{C}$ przez 4 dni w celu nasycenia $\mathrm{CO}_{2}$. Następnie napoje schładzano do temp. $5^{\circ} \mathrm{C}$ i wychłodzone poddawano ocenie.

Oznaczano zawartość: alkoholu [10], tłuszczu [\%], białka [\%], sacharydów [\%] analizatorem składu chemicznego mleka Bentley B-150 (Bentley, USA). Kwasowość czynną w serwatkach oznaczano pH-metrem FiveEasy PLUS FP20 (Mettler Toledo, Szwajcaria) wyposażonym w elektrodę LE438 ze zintegrowanym czujnikiem temperatury. Kwasowość całkowitą oznaczano zgodnie z wytycznymi Jemaa i wsp. [12], a wyniki podano w gramach kwasu mlekowego na litr.

Ocenę sensoryczną wychłodzonych i nasyconych $\mathrm{CO}_{2}$ napojów z laktozą i niskolaktozowych wykonywano po zakończeniu produkcji i wychłodzeniu. Do oceny sensorycznej zastosowano metody profilowania sensorycznego [21, 22]. Oceniano: wygląd, nasycenie $\mathrm{CO}_{2}$, barwę, klarowność, smak: kwaśny, słodki, obcy, gorzki, drożdżowy, wyczuwalność alkoholu, intensywność aromatu, trwałość aromatu i smaku oraz obecność zapachu obcego. Odpowiednio przeszkolony 20-osobowy panel oceniał zakodowane próbki pod względem intensywności występowania ocenianej cechy. Badający podawali swoją ocenę na kartach ze skalą liniową podzieloną na 9 odcinków, z ozna- 
czeniami na obu jej końcach w przypadku oceny konsystencji i barwy: na lewym (1 jednostka): „mało charakterystyczna” i na prawym (9 jednostek) „bardzo charakterystyczna”. W ocenie smaku i zapachu oznaczeniami brzegowymi były „niewyczuwalny” i „bardzo intensywny” [21, 22]. Ocena pożądalności polegała na uszeregowaniu próbek według kolejności od najbardziej pożądanej (najlepszej) do najmniej pożądanej (najgorszej).

Doświadczenie wykonano w pięciu niezależnych powtórzeniach w każdej grupie. Obliczenia statystyczne wykonano z użyciem programu Statistica ver. 12. Przeprowadzono jednoczynnikową i dwuczynnikową analizę wariancji, a istotność pomiędzy wartościami średnimi weryfikowano testem Tukeya przy $\mathrm{p}<0,05$.

\section{Wyniki i dyskusja}

Optymalizacja warunków do fermentacji i rozwoju drożdży wymagała obniżenia pH serwatki do poziomu zbliżonego do $\mathrm{pH}$ moszczów. W niektórych badaniach [2] wykazano, że $\mathrm{pH}$ środowiska o wartościach $3 \div 5$ nie wpływa tak istotnie na parametry wzrostu drożdży S. bayanus jak temperatura. Jednak Serra i wsp. [24] twierdzą, że zmniejszenie wartości $\mathrm{pH}$ powoduje wyższe zapotrzebowanie na energię do aktywacji rozwoju szczepu $S$. cerevisiae niż szczepu $S$. bayanus $\left(415 \mathrm{cal} \cdot \mathrm{mol}^{-1} /\right.$ jednostkę $\mathrm{pH}$ dla S. cerevisiae, ale tylko $247 \mathrm{cal} \cdot \mathrm{mol} \cdot \mathrm{mol}^{-1} /$ jednostkę $\mathrm{pH}$ dla $S$. bayanus).

Po fermentacji mlekowej istotnie wyższą kwasowość całkowitą stwierdzono w serwatce niskolaktozowej w porównaniu z serwatką zawierającą niezhydrolizowaną laktozę (tab. 1). Również wartości pH różniły się istotnie w serwatce z laktozą $(4,58)$ i niskolaktozowej $(4,49)$. Zawartość białka wynosiła $0,56 \div 0,60 \%$, a tłuszczu $-0,24 \div$ $0,25 \%$ (tab. 1). Według Król i wsp. [14] zawartość białka w serwatkach mieści się w przedziale $1,22 \div 1,66 \%$, a tłuszczu wynosi tylko $0,06 \%$. Zawartość tłuszczu odgrywa bardzo ważną rolę $\mathrm{w}$ dalszych procesach przetwarzania serwatki, ponieważ wpływa na zmiany smaku i zapachu. Jest on bowiem prekursorem wielu lotnych kwasów i aldehydów. Proces ten jest stymulowany głównie przez podwyższoną temperaturę i światło słoneczne, dlatego w produkcji przemysłowej korzystne byłoby minimalizowanie udziału tych czynników i zmniejszenie zawartości tłuszczu [25].

Po pasteryzacji, filtracji i dosłodzeniu serwatki przeznaczone do produkcji napojów: z naturalną zawartością laktozy i niskolaktozowa zawierały odpowiednio: 5,56 i $5,58 \%$ sacharydów (tab. 2).

Drożdże Saccharomyces bayanus w serwatce niskolaktozowej lepiej wykorzystywały sacharydy, gdyż w nastawach tych stwierdzono istotnie mniejszą zawartość sacharydów w 7., 14. i 21. dniu fermentacji. W ostatnim dniu fermentacji w serwatce niskolaktozowej było nieistotnie mniej sacharydów niż w serwatce z laktozą. Wraz z wydłużaniem czasu fermentacji zwiększała się zawartość białka w obu serwatkach (tab. 
3). Drożdże $S$. bayanus w temp. $21-25^{\circ} \mathrm{C}$ charakteryzują się produktywnością biomasy na poziomie $0,083 \div 0,090 \mathrm{~g} \cdot 1^{-1} \cdot \mathrm{h}^{-1}$, która zwiększa ilość białka w nastawach [24].

Tabela 1. Zawartość tłuszczu, białka i sacharydów oraz kwasowość serwatki po fermentacji mlekowej i rozkładzie laktozy

Table 1. Content of fat, protein, and saccharides in, and acidity of whey after lactic fermentation and lactose degradation

\begin{tabular}{||l|c|c||}
\hline \multirow{2}{*}{\multicolumn{1}{||}{ Parametr / Parameter }} & \multicolumn{2}{|c||}{ Rodzaj serwatki / Type of whey } \\
\cline { 2 - 3 } & $\begin{array}{c}\text { z naturalną zawartością } \\
\text { laktozy / with natural lacto- } \\
\text { se content }\end{array}$ & $\begin{array}{c}\text { niskolaktozowa } \\
\text { low-lactose whey }\end{array}$ \\
\hline $\begin{array}{l}\text { Kwasowość całkowita [g kwasu mlekowego/l] } \\
\text { Total acidity [g lactic acid/1] }\end{array}$ & $0,34^{\mathrm{a}} \pm 0,02$ & $0,40^{\mathrm{b}} \pm 0,01$ \\
\hline $\mathrm{pH}$ & $4,58^{\mathrm{a}} \pm 0,01$ & $4,49^{\mathrm{b}} \pm 0,01$ \\
\hline Tłuszcz / Fat [\%] & $0,24^{\mathrm{a}} \pm 0,01$ & $0,25^{\mathrm{a}} \pm 0,00$ \\
\hline Białko / Protein [\%] & $0,56^{\mathrm{a}} \pm 0,00$ & $0,60^{\mathrm{b}} \pm 0,01$ \\
\hline Sacharydy / Saccharides [\%] & $4,52^{\mathrm{a}} \pm 0,02$ & $4,54^{\mathrm{a}} \pm 0,02$ \\
\hline
\end{tabular}

Objaśnienia / Explanatory notes:

$\mathrm{W}$ tabeli przedstawiono wartości średnie \pm odchylenia standardowe / Table shows mean values \pm standard deviations; $\mathrm{n}=5$; $\mathrm{a}, \mathrm{b}, \mathrm{c}$ - wartości średnie $\mathrm{w}$ wierszach oznaczone różnymi literami różnią się statystycznie istotnie $(p<0,05) /$ mean values in rows and denoted by different letters differ statistically significantly at $\mathrm{p}<0.05$.

Tabela 2. Zawartość sacharydów w serwatkach podczas 28 dni fermentacji alkoholowej

Table 2. Content of saccharides in whey during 28 days of alcoholic fermentation

\begin{tabular}{|c|c|c||}
\hline \multirow{2}{*}{$\begin{array}{c}\text { Czas fermentacji [dni] } \\
\text { Fermentation time [days] }\end{array}$} & $\begin{array}{c}|c| \\
\text { Serwatka z naturalną zawartością lakto- } \\
\text { zy / With natural lactose content }\end{array}$ & $\begin{array}{c}\text { Serwatka niskolaktozowa } \\
\text { Low-lactose whey }\end{array}$ \\
\hline 0 & $5,56^{\mathrm{aA}} \pm 0,01$ & $5,58^{\mathrm{aA}} \pm 0,02$ \\
\hline 7 & $6,41^{\mathrm{aB}} \pm 0,00$ & $5,84^{\mathrm{bB}} \pm 0,06$ \\
\hline 14 & $8,05^{\mathrm{aC}} \pm 0,07$ & $7,35^{\mathrm{bC}} \pm 0,05$ \\
\hline 21 & $8,87^{\mathrm{aD}} \pm 0,01$ & $8,17^{\mathrm{bD}} \pm 0,09$ \\
\hline 28 & $9,83^{\mathrm{aE}} \pm 0,01$ & $9,77^{\mathrm{aE}} \pm 0,15$ \\
\hline
\end{tabular}

Objaśnienia / Explanatory notes:

W tabeli przedstawiono wartości średnie \pm odchylenia standardowe / Table shows mean values \pm standard deviations; $\mathrm{n}=5$; $\mathrm{a}, \mathrm{b}, \mathrm{c}$ - wartości średnie $\mathrm{w}$ wierszach oznaczone różnymi literami różnią się statystycznie istotnie $(\mathrm{p}<0,05) /$ mean values in rows and denoted by different letters differ statistically significantly at $\mathrm{p}<0.05$; A, B, C, D, E - wartości średnie w kolumnach oznaczone różnymi literami różnią się statystycznie istotnie $(p<0,05) /$ mean values in columns and denoted by different letters differ statistically significantly at $\mathrm{p}<0.05$. 
Tabela 3. Zawartość białka w napojach podczas 28 dni fermentacji alkoholowej

Table 3. Content of protein in whey during 28 days of alcoholic fermentation

\begin{tabular}{|c|c|c||}
\hline \multirow{2}{*}{$\begin{array}{c}\text { Czas fermentacji [dni] } \\
\text { Fermentation time [days] }\end{array}$} & \multicolumn{2}{|c|}{ Białko / Protein [\%] } \\
\cline { 2 - 3 } & $\begin{array}{c}\text { Serwatka z naturalną zawartością laktozy } \\
\text { With natural lactose content }\end{array}$ & $\begin{array}{c}\text { Serwatka niskolaktozowa } \\
\text { Low-lactose whey }\end{array}$ \\
\hline 0 & $0,39^{\mathrm{aA}} \pm 0,01$ & $0,40^{\mathrm{aA}} \pm 0,01$ \\
\hline 7 & $0,39^{\mathrm{aA}} \pm 0,01$ & $0,40^{\mathrm{aA}} \pm 0,01$ \\
\hline 14 & $0,41^{\mathrm{aB}} \pm 0,01$ & $0,42^{\mathrm{aB}} \pm 0,01$ \\
\hline 21 & $0,42^{\mathrm{aB}} \pm 0,01$ & $0,42^{\mathrm{aB}} \pm 0,01$ \\
\hline 28 & $0,42^{\mathrm{aB}} \pm 0,01$ & $0,43^{\mathrm{aB}} \pm 0,01$ \\
\hline
\end{tabular}

Objaśnienia jak pod tab. 2 / Explanatory notes as in Tab. 2.

Podczas 28 dni fermentacji serwatek stwierdzono istotne obniżenie poziomu $\mathrm{pH}$ zarówno w nastawach z naturalną zawartością laktozy, jak i niskolaktozowych (tab. 4). W nastawach naturalnych wartość pH obniżyła się o 0,5 jednostki, a w niskolaktozowych - o 0,45 jednostki. Równocześnie odnotowano systematyczny wzrost kwasowości całkowitej w czasie fermentacji alkoholowej (tab. 5). Istotnie wyższą kwasowość początkową wykazano w nastawach serwatki niskolaktozowej w porównaniu z tradycyjną, jednak po 28 dniach fermentacji różnice te nie były już statystycznie istotne.

Tabela 4. Kwasowość czynna $(\mathrm{pH})$ w napojach podczas 28 dni fermentacji

Table 4. Active acidity $(\mathrm{pH})$ of beverages during 28 days of fermentation

\begin{tabular}{||c|c|c||}
\hline \hline \multirow{2}{*}{$\begin{array}{c}\text { Czas fermentacji [dni] } \\
\text { Fermentation time [days] }\end{array}$} & \multicolumn{2}{|c|}{$\mathrm{pH}$} \\
\cline { 2 - 3 } & $\begin{array}{c}\text { Serwatka z naturalną zawartością laktozy } \\
\text { Whey with natural lactose content }\end{array}$ & $\begin{array}{c}\text { Serwatka niskolaktozowa } \\
\text { Low-lactose whey }\end{array}$ \\
\hline 0 & $4,56^{\mathrm{bE}} \pm 0,01$ & $4,50^{\mathrm{aD}} \pm 0,02$ \\
\hline 7 & $4,39^{\mathrm{aD}} \pm 0,01$ & $4,35^{\mathrm{bC}} \pm 0,01$ \\
\hline 14 & $4,20^{\mathrm{aC}} \pm 0,02$ & $4,16^{\mathrm{aB}} \pm 0,02$ \\
\hline 21 & $4,19^{\mathrm{bB}} \pm 0,00$ & $4,09^{\mathrm{aA}} \pm 0,00$ \\
\hline 28 & $4,06^{\mathrm{aA}} \pm 0,00$ & $4,05^{\mathrm{aA}} \pm 0,01$ \\
\hline
\end{tabular}

Objaśnienia jak pod tab. 2./ Explanatory notes as in Tab. 2.

Podczas fermentacji alkoholowej wytwarzane są produkty uboczne odpowiedzialne za kwasowość, takie jak: kwas mlekowy, aldehyd octowy, kwas pirogronowy, kwas octowy, glicerol i kwas bursztynowy [29]. Francesca i wsp. [8] zaobserwowali podczas monitorowanych winifikacji, że pH oraz zawartość kwasów lotnych wzrosły, natomiast w przypadku kwasowości całkowitej stwierdzili przeciwne tendencje.

Jak podają Volschenk i wsp. [27], kwasowość ogólna odgrywa bardzo istotną rolę w kształtowaniu sensorycznej jakości i stabilności wina. Przyjmuje się że najkorzyst- 
niejszy przedział kwasowości ogólnej wynosi $4 \div 6 \mathrm{~g} / 1$. Satora [23], w pracy dotyczącej wpływu kultur mieszanych $S$. cerevisiae i $S$. bayanus lub $S$. cerevisiae i $S$. paradoxus na fermentację moszczów jabłkowych, także wykazał wzrost kwasowości ogólnej w trakcie fermentacji. Największą zawartość kwasów wymieniony autor odnotował w napojach wyprodukowanych z udziałem monokultury szczepu $S$. bayanus $(9,24 \mathrm{~g} / 1)$ i był to wzrost kwasowości o 1,58 g/1 w odniesieniu do wartości początkowej. W badaniach własnych całkowita kwasowość serwatek po 28 dniach fermentacji wzrosła o $0,31 \mathrm{~g} / 1$ (z laktozą) i o $0,23 \mathrm{~g} / 1$ (niskolaktozowej).

W napojach serwatkowych po refermentacji, nasyconych $\mathrm{CO}_{2}$, oznaczono podstawowe właściwości fizykochemiczne (tab. 6). Napoje różniły się istotnie pod względem zawartości sacharydów i alkoholu. Pozostałe cechy, takie jak: zawartość białka i tłuszczu oraz $\mathrm{pH}$ i kwasowość były porównywalne w obu rodzajach napojów. W napojach z serwatki uzyskano $8,5 \div 9,5 \%$ obj. alkoholu, odpowiednio: w serwatce z laktozą i niskolaktozowej.

Tabela 5. Kwasowość całkowita serwatek podczas 28 dni fermentacji alkoholowej Table 5. Total acidity of whey during 28 days of alcoholic fermentation

\begin{tabular}{|c|c|c||}
\hline \multirow{2}{*}{$\begin{array}{c}\text { Czas fermentacji [dni] } \\
\text { Fermentation time [days] }\end{array}$} & \multicolumn{2}{|c|}{$\begin{array}{c}\text { Kwasowość całkowita [g kwasu mlekowego na litr] } \\
\text { Total acidity [g lactic acid/liter] }\end{array}$} \\
\cline { 2 - 3 } & $\begin{array}{c}\text { Serwatka z naturalną zawartością laktozy } \\
\text { Whey with natural lactose content }\end{array}$ & $\begin{array}{c}\text { Serwatka niskolaktozowa } \\
\text { Low-lactose whey }\end{array}$ \\
\hline 0 & $0,36^{\mathrm{aA}} \pm 0,05$ & $0,46^{\mathrm{bA}} \pm 0,03$ \\
\hline 7 & $0,43^{\mathrm{aAB}} \pm 0,05$ & $0,51^{\mathrm{bB}} \pm 0,01$ \\
\hline 14 & $0,47^{\mathrm{aB}} \pm 0,00$ & $0,60^{\mathrm{bC}} \pm 0,00$ \\
\hline 21 & $0,54^{\mathrm{aC}} \pm 0,01$ & $0,64^{\mathrm{bD}} \pm 0,01$ \\
\hline 28 & $0,67^{\mathrm{aD}} \pm 0,01$ & $0,69^{\mathrm{aE}} \pm 0,02$ \\
\hline
\end{tabular}

Objaśnienia jak pod tab. 2./ Explanatory notes as in Tab. 2.

Bonin i Wzorek [4] w ciągu ponad 3-miesięcznej fermentacji moszczów gronowych z użyciem Saccharomyces bayanus uzyskali wina o mocy: 14,1 \% oraz 13,3\% obj. alkoholu. Bugajewska i Wzorek [5] po 21 dniach fermentacji moszczu gronowego przez drożdże $S$. bayanus rasy Bratysława, przy początkowej zawartości cukrów 330 g/l, uzyskali 19,2 \% obj. alkoholu. Czyżycki [6] oraz Bonin i Kolwas [3] stwierdzili, że Saccharomyces bayanus charakteryzuje się znaczną osmofilnością i zdolnością fermentacji nastawów do zawartości alkoholu $15 \div 18 \%$ obj. etanolu.

Zespół oceniający wskazał na napój serwatkowy o obniżonej zawartości laktozy jako ten, który cechował się lepszymi właściwościami sensorycznymi i był bardziej pożądany przez konsumentów (tab. 7). Napój niskolaktozowy cechował się lepszym wyglądem, barwą, klarownością oraz był słodszy od napoju z laktozą. W napoju przy- 
gotowanym z serwatki z niezhydrolizowaną laktozą oznaczono istotnie większą

Tabela 6. Zawartość tłuszczu, białka, sacharydów i alkoholu oraz kwasowość napojów po refermentacji

Table 6. Content of fat, protein, saccharides, alcohol in and acidity of whey beverages after fermentation

\begin{tabular}{|c|c|c||}
\hline \multirow{2}{*}{$\begin{array}{c}\text { Parametr } \\
\text { Parameter }\end{array}$} & \multicolumn{2}{|c||}{ Napój z serwatki / Whey beverage } \\
\cline { 2 - 3 } & $\begin{array}{c}\text { Serwatka z naturalną zawartością laktozy } \\
\text { Whey with natural lactose content }\end{array}$ & $\begin{array}{c}\text { Serwatka niskolaktozowa } \\
\text { Low-lactose whey }\end{array}$ \\
\hline $\begin{array}{c}\text { Kwasowość całkowita } \\
\text { Total acidity [g/l] }\end{array}$ & $0,87^{\mathrm{a}} \pm 0,01$ & $0,89^{\mathrm{a}} \pm 0,02$ \\
\hline $\mathrm{pH}$ & $4,00^{\mathrm{a}} \pm 0,00$ & $3,98^{\mathrm{a}} \pm 0,01$ \\
\hline Tłuszcz /Fat [\%] & $0,20^{\mathrm{a}} \pm 0,04$ & $0,18^{\mathrm{a}} \pm 0,07$ \\
\hline Białko / Protein [\%] & $0,26^{\mathrm{a}} \pm 0,01$ & $0,28^{\mathrm{a}} \pm 0,01$ \\
\hline Sacharydy / Saccharides [\%] & $11,83^{\mathrm{b}} \pm 0,01$ & $11,77^{\mathrm{a}} \pm 0,15$ \\
\hline Alkohol /Alcohol [\%] & $8,50^{\mathrm{a}} \pm 0,50$ & $9,50^{\mathrm{b}} \pm 0,50$ \\
\hline
\end{tabular}

Objaśnienia jak pod tab. 1./ Explanatory notes as in Tab. 1.

zawartość sacharydów, jednak laktoza (wchodząca w skład sacharydów) charakteryzuje się mniejszą słodyczą niż glukoza i sacharoza, co przyczyniło się do zmniejszenia intensywności odczucia smaku słodkiego przez oceniających. Według Pawlos i wsp. [20] rodzaj cukrów zawartych lub dodanych do napojów serwatkowych ma wpływ na smak i preferencje. Z kolei Landge i Gaikwad [16] badali wpływ różnych stężeń sacharozy w napojach wyprodukowanych z serwatek aromatyzowanych zmieloną kolendrą oraz kminkiem i wykazali, że większa zawartość sacharozy korzystnie wpływa na wygląd i barwę gotowych napojów w czasie przechowywania. Należy zaznaczyć, że grupy karbonylowe $\mathrm{w}$ laktozie mogą łatwo reagować z grupami aminowymi białek, w wyniku czego powstają hydroksymetylofurfural, pentozydyna oraz melanoidyny powodujące brązowienie i zmiany smakowo-zapachowe przerobionej serwatki [15]. Jak zauważają Kourkoutas i wsp. [13], aktywność metaboliczna drożdży, zwłaszcza metabolizm aminokwasów, ma bardzo istotny wpływ na smak uzyskiwanych napojów, gdyż jest on związany z produkcją związków, takich jak: diketony, estry, wyższe alkohole, aldehydy, kwasy thuszczowe i związki siarki. Dodatkowo przekształcenie enzymatyczne wolnych aminokwasów często prowadzi do powstawania związków lotnych, odpowiedzialnych za ostry, nieprzyjemny smak i zapach [15]. Smak i zapach napojów z serwatki o tradycyjnej zawartości laktozy i niskolaktozowej nie wskazywał na niekorzystne zmiany wynikające z reakcji chemicznych i enzymatycznych. Oznaczona istotnie większa zawartość alkoholu w napojach niskolaktozowych w porównaniu z zawierającymi laktozę nie była wyczuwalna i zauważona przez oceniających. 
Tabela 7. Wyniki oceny sensorycznej napojów serwatkowych naturalnie nasyconych $\mathrm{CO}_{2}$ o smaku mango-marakuja

Table 7. Sensory evaluation of whey beverages, naturally saturated with $\mathrm{CO}_{2}$, having mango and passion fruit flavour

\begin{tabular}{|c|c|c|}
\hline \multirow[b]{2}{*}{ Cecha / Attribute } & \multicolumn{2}{|c|}{ Napój z serwatki / Whey beverage } \\
\hline & $\begin{array}{l}\text { Serwatka z naturalną zawartością laktozy } \\
\text { Whey with natural lactose content } \\
(\mathrm{n}=20)\end{array}$ & $\begin{array}{l}\text { Serwatka niskolaktozowa } \\
\text { Low-lactose whey } \\
(\mathrm{n}=20)\end{array}$ \\
\hline Preferencje / Preferences & $1,27^{\mathrm{a}} \pm 0,27$ & $0,64^{\mathrm{b}} \pm 0,29$ \\
\hline Wygląd / Appearance & $5,00^{\mathrm{a}} \pm 1,34$ & $6,45^{\mathrm{b}} \pm 1,63$ \\
\hline Wysycenie $\mathrm{CO}_{2} / \mathrm{CO}_{2}$ saturation & $5,36^{\mathrm{a}} \pm 1,29$ & $5,28^{\mathrm{a}} \pm 1,66$ \\
\hline Barwa / Colour & $4,55^{\mathrm{a}} \pm 1,13$ & $7,00^{\mathrm{b}} \pm 1,61$ \\
\hline Klarowność / Clarity & $3,82^{\mathrm{a}} \pm 1,33$ & $4,64^{\mathrm{a}} \pm 1,57$ \\
\hline Smak kwaśny / Sour taste & $4,45^{\mathrm{a}} \pm 1,37$ & $3,55^{\mathrm{a}} \pm 1,37$ \\
\hline Smak słodki / Sweet taste & $4,91^{\mathrm{a}} \pm 1,76$ & $5,00^{\mathrm{a}} \pm 1,79$ \\
\hline Smak obcy / Foreign taste & $2,73^{\mathrm{a}} \pm 1,62$ & $2,72^{\mathrm{a}} \pm 1,25$ \\
\hline Gorycz / Bitterness & $4,00^{\mathrm{a}} \pm 1,61$ & $4,00^{\mathrm{a}} \pm 1,26$ \\
\hline Smak drożdżowy / Yeasty taste & $3,82^{\mathrm{a}} \pm 1,60$ & $4,18^{\mathrm{a}} \pm 1,66$ \\
\hline $\begin{array}{l}\text { Wyczuwalność alkoholu } \\
\text { Perceptible alcohol }\end{array}$ & $3,13^{\mathrm{a}} \pm 1,10$ & $3,18^{\mathrm{a}} \pm 2,14$ \\
\hline $\begin{array}{l}\text { Intensywność aromatu } \\
\text { Intensity of aroma }\end{array}$ & $5,81^{\mathrm{a}} \pm 1,58$ & $5,82^{\mathrm{a}} \pm 1,54$ \\
\hline $\begin{array}{l}\text { Trwałość aromatu i smaku } \\
\text { Stability of aroma and taste }\end{array}$ & $5,73^{\mathrm{a}} \pm 0,73$ & $5,59^{\mathrm{a}} \pm 1,70$ \\
\hline Zapach obcy / Foreign smell & $3,27^{\mathrm{a}} \pm 1,49$ & $3,18^{\mathrm{a}} \pm 1,78$ \\
\hline
\end{tabular}

Objaśnienia / Explanatory notes:

W tabeli przedstawiono wartości średnie \pm odchylenia standardowe / Table shows mean values \pm standard deviations; $\mathrm{n}=20$; $\mathrm{a}, \mathrm{b}, \mathrm{c}$ - wartości średnie $\mathrm{w}$ wierszach oznaczone różnymi literami różnią się statystycznie istotnie $(\mathrm{p}<0,05) /$ mean values in rows and denoted by different letters differ statistically significantly at $\mathrm{p}<0.05$.

\section{Wnioski}

1. Drożdże Saccharomyces bayanus G995 mogą być wykorzystywane do produkcji napojów z serwatki z naturalną zawartością laktozy i niskolaktozowej, nasyconych $\mathrm{CO}_{2}$. Po 28 dniach fermentacji wyższą o $1 \%$ zawartość alkoholu stwierdzono w napojach niskolaktozowych $(9,50 \%)$ w porównaniu z napojami z tradycyjną zawartością laktozy $(8,50 \%)$. 
2. Podczas 28 dni fermentacji w nastawach serwatki z naturalną zawartością laktozy wartość pH obniżyła się z 4,56 o 0,5 jednostki, a w nastawach niskolaktozowych z 4,50 o 0,45 jednostki.

3. Napoje otrzymane z serwatki niskolaktozowej charakteryzowały się lepszą klarownością i barwą oraz intensywniejszym słodszym smakiem w porównaniu z napojami wyprodukowanymi z serwatki o tradycyjnej zawartości laktozy.

\section{Literatura}

[1] Andrzejewska M.: Nietolerancja laktozy, istotne zagadnienia żywieniowe i medyczne. Żyw. Człow. Metab., 2015, 4, 250-254.

[2] Arroyo-López F.N., Orlić S., Querol A., Barrio E.: Effects of temperature, pH and sugar concentration on the growth parameters of Saccharomyces cerevisiae, S. kudriavzevii and their interspecific hybrid. Int. J. Food Microbiol., 2009, 131 (2-3), 120-127.

[3] Bonin S., Kolwas M.: Fermentacja nastawów wysokocukrowych z dodatkiem preparatu ścian komórkowych. Przem. Ferm. Owoc.Warz., 2009, 5, 6-8.

[4] Bonin S., Wzorek W.: Porównanie ciągłych fermentacji winiarskich prowadzonych z użyciem dwóch szczepów drożdży immobilizowanych na szkle piankowym. Acta Sci. Pol. Technol. Aliment., 2004, 3 (2), 83-93.

[5] Bugajewska A., Wzorek W.: Wpływ wybranych aktywatorów i postaci użytych drożdży na fermentacje winiarską. Przem. Ferm. Owoc.Warz., 1995, 6, 20-22.

[6] Czyżycki A.: Zastosowanie suszonych drożdży do fermentacji win. Przem. Ferm. Owoc. Warz., 1994, 3 (38), 14-16.

[7] Drgalić I., Tratnik L., Božanić R.: Growth and survival of probiotic bacteria in reconstituted whey. Lait, 2005, 85, 171-179.

[8] Francesca N., Romano R., Sannino C., Grottaglie L.L, Settani L., Moschetti G.: Evolution of microbiological and chemical parameters during red wine making with extended post-fermentation maceration. Int. J. Food Microbiol., 2014, 171, 84-94.

[9] Glibowski P., Sołowiej B., Nastaj M., Rajca M.: Właściwości reologiczne i teksturalne mimetyków napojów fermentowanych otrzymywanych na bazie inuliny i serwatki. W: Technologiczne kształtowanie jakości żywności. Red. K.M Wójciak i Z.J. Dolatowski. Wyd. Nauk. PTTŻ, Kraków 2015, ss. 59-68.

[10] Gonchar M.V., Maidan M.M., Pavlishko H.M., Sibirny A.A.: A new oxidase-peroxidase kit for ethanol assays in alcoholic beverages. Food Technol. Biotechnol., 2001, 39 (1), 37-42.

[11] Grajek W., Szymanowska D.: Stresy środowiskowe działające na drożdże Saccharomyces cerevisiae w procesie fermentacji etanolowej. Biotechnologia, 2008, 3 (82), 46-63.

[12] Jemaa M.B., Falleh H., Neves M.A., Isoda H., Nakajima M., Ksouri R.: Quality preservation of deliberately contaminated milk using thyme free and nanoemulsified essential oils. Food Chem., 2017, 217, 726-734.

[13] Kourkoutas Y., Bekatorou A., Banat I.M., Marchant R., Koutinas A.: Immobilization technologies and support materials suitable in alcohol beverages production: A review. Food Microbiol., 2004, 8 (21), 377-397.

[14] Król J., Brodziak A., Litwińczuk A.: Podstawowy skład chemiczny i zawartość wybranych białek serwatkowych w mleku krów różnych ras i w serwatce podpuszczkowej. Żywność. Nauka. Technologia. Jakość, 2011, 4 (77), 74-83. 
[15] Kumider J.: Optymalizacja odpadów przemysłu rolno-spożywczego. W: Aspekty towaroznawcze i ekologiczne. Red. Wyd. AE w Poznaniu, Poznań 1996, ss. 1-110.

[16] Landge S.N., Gaikwad S.M.: Studies on preparation and sensory evaluation of whey beverage. Int. J. Food Agric. Veter. Sci., 2013, 3 (3), 27-29.

[17] Matijević B., Boźanić R., Tratnik L.: The influence of lactulose on growth and survival of probiotic bacteria Lactobacillus acidophilus La-5 and Bifidobacterium animalis subsp. lactis BB-12 in reconstituted sweet whey. Mljekarstvo, 2009, 59 (1), 20-27.

[18] Matijević B., Lisak K., Božanić R., Tratnik L.: Impact of enzymatic hydrolyzed lactose on fermentation and growth of probiotic bacteria in whey. Mljekarstvo, 2011, 61 (2), 154-160.

[19] Naumov G.I., Naumova E.S., Martynenko N.N., Masneuf-Pomaréde I.: Taxonomy, ecology, and genetics of the yeast Saccharomyces bayanus: A new object for science and practice. Microbiology, 2011, 80 (6), 735-742.

[20] Pawlos M., Szajnar K., Znamirowska A., Kalicka D.: Wpływ rodzaju cukru, czasu i warunków przechowywania na jakość napojów serwatkowych o smaku cytrynowym. Badania i rozwój młodych naukowców w Polsce. W: Żywność. Red. J. Nyćkowiak i J. Leśny. Wyd. Młodzi Naukowcy, Poznań 2016, ss. 59-67.

[21] PN-ISO 11035:1999. Analiza sensoryczna. Identyfikacja i wybór deskryptorów do ustalania profilu sensorycznego z użyciem metod wielowymiarowych.

[22] PN-ISO 4121:1998. Analiza sensoryczna. Metodologia. Ocena produktów żywnościowych przy użyciu metod skalowania.

[23] Satora P.: Wpływ kultur mieszanych S. cerevisiae i S. bayanus na fermentację moszczów jabłkowych. Zesz. Nauk. UR w Krakowie. Rozprawy. Wyd. UR. Kraków 2011.

[24] Serra A., Strehaiano P., Taillandier P.: Influence of temperature and $\mathrm{pH}$ on Saccharomyces bayanus var. uvarum growth; impact of a wine yeast interspecific hybridization on these parameters. Int. J. Food Microbiol., 2005, 104, 257-265.

[25] Silviya R.M., Bhumika K., Dabhi Parmar S.C., Aparnathi K.D.: Whey and its utilization. Int. J. Curr. Microbiol. App. Sci., 2016, 5 (8), 134-155.

[26] Skryplonek K., Jasińska M.: Jakość fermentowanych napojów probiotycznych otrzymanych z mrożonej serwatki kwasowej i mleka w czasie chłodniczego przechowywania. Żywność. Nauka. Technologia. Jakość, 2016, 1 (104), 32-44.

[27] Volschenk H., Viljoen-Bloom M., Subden R.E., van Vuuren H.J.J.: Malo-etanolic fermentation in grape must by recombinant strains of Saccharomyces cerevisiae. Yest, 2001,18, 963-970.

[28] Wanarska M., Kur J.: $\beta$-D-galaktozydazy - źródła, właściwości i zastosowanie. Biotechnologia, 2005, 3 (71), 46-62.

[29] Wesołowska-Trojanowska M., Targoński Z.: Wykorzystanie serwatki w procesach biotechnologicznych. Nauki Inżynierskie i Technologiczne, 2014, 1 (12), 102-116.

[30] Znamirowska A., Kalicka D., Szajnar K., Pawlos M.: Właściwości organoleptyczne napojów serwatkowych o smaku kawowym, cytrynowym, malinowym i mango - maracuja. W: Bezpieczeństwo żywności. Red. C. Puchalski i M. Dżugan. Wyd. UR, Rzeszów 2015, ss. 37-50. 


\title{
DYNAMICS OF FERMENTING LOW-LACTOSE WHEY BY SACCHAROMYCES BAYANUS (BAYANUS G995) AND QUALITY OF WHEY BEVERAGES
}

\author{
S u m m a ry
}

The enzymatic degradation of lactose in whey by $\beta$-galactosidase makes it possible to intensify alcoholic fermentation through increasing the availability of sugars and the possibility of applying strains of non-lactose fermenting bacteria, which are traditionally used in the production of alcoholic beverages.

The objective of the study was to evaluate the possibility of using BAYANUS G995 yeast (Spirit Ferm., Sweden) and to determine the dynamics of fermenting whey with a natural content of lactose and low-lactose whey. The paper presents the results of quality evaluation of whey beverages saturated with $\mathrm{CO}_{2}$.

The alcoholic fermentation was performed at $23{ }^{\circ} \mathrm{C}$ during a period of 28 days. Every 7 days, sucrose was added to the whey under fermentation. Once a week, there were monitored: content of saccharides, content of protein, $\mathrm{pH}$ value, total acidity, and, after the fermentation, content of alcohol. After 28 days, whey beverages were decanted, flavouring innards were added, and the beverages were sweetened using sucrose. The whey beverages were fermented at a temperature of $25^{\circ} \mathrm{C}$ during a period of 4 days to saturate them with carbon dioxide. Next, the beverages were chilled down to $5^{\circ} \mathrm{C}$ and underwent sensory and physical-chemical analysis. Saccharomyces bayanus can be utilized in the production of carbonated beverages made from whey with a natural content of lactose and from low-lactose whey. After 28 days of fermentation, it was found that the content of alcohol in the low-lactose beverages was $1 \%$ higher compared to that in the whey beverages with the natural content of lactose: $9.50 \%$ and $8.50 \%$, respectively. During the 28 day fermentation period, the $\mathrm{pH}$ value of the whey fermented decreased by 0.5 unit (from a value of 4.56 to 4.06 ) whereas that of the low-lactose whey decreased by 0.45 unit (from a value of 4.50 to 4.05). During fermentation, a systematic increase was also recorded in total acidity of the whey with natural content of lactose (from $0.36 \mathrm{~g} / 1$ (on 0 day of fermentation) to $0.67 \mathrm{~g} / 1$ (on the $28^{\text {th }}$ day of fermentation) as well as of the low-lactose whey (from $0.46 \mathrm{~g} / 1$ (on 0 day of fermentation) to $0.69 \mathrm{~g} / 1$ on the $28^{\text {th }}$ day of fermentation). The beverages produced from the low-lactose whey were characterized by a better clarity, better colour, and by a more intense sweet flavour in comparison with the beverages made from whey with a natural content of lactose.

Key words: whey, Saccharomyces bayanus, low-lactose beverages, fermentation 